\title{
Towards an Anarchist Philosophy of Education
}

\section{Judith Suissa}

Two discernible trends can be found in recent work in philosophy of education, giving rise to significant internal tensions and debates. In what follows, I will identify the form and some of the key features of these trends, and suggest how a critical, anarchist-inspired perspective on them can offer some fruitful ways of thinking about the important philosophical and practical educational questions that they address. I am not referring to 'rival conceptions' (Standish, 2007) of the discipline, or to the distinction between 'analytic' and 'continental' traditions. What I want to draw attention to is not primarily a question of philosophical tradition(s), style or method, but rather a question of how the relationship between education, schooling, the state and social change is conceptualized, and how this in turn structures the way we bring philosophical arguments to bear on educational questions. I do not claim to offer an exhaustive description of the current state of the discipline; there are certainly important themes developed by philosophers of education that do not fall neatly into this account. However, I do think that the themes I identify are significant in terms of their influence in setting the terms of the debate in which so much of our academic discussion takes place.

One strand is concerned chiefly with offering a clear, normative account of "what education is for" that will, it is supposed, be of use to policy makers, teachers, educational theorists and, to a lesser extent, parents. Most of the work within this area is conducted in the form of tightly constructed philosophical argument, although it often draws on policy analysis, empirical sociology and history. In addition, the language in which it talks of education is predominantly that of the formal school system: curricula, teacher training, and policies on access and provision. It is important to note that while this kind of work has obvious intellectual antecedents in what is usually referred to as the analytic tradition in philosophy of 
education, it has moved away from this tradition in significant ways. Although, as John White points out (White, 2010), it is doubtful whether even the classic work by key figures in this tradition such as Hirst, Peters, Dearden and Elliot was ever as narrowly confined to conceptual analysis, committed to social atomism, suspicious of articulating norms and values, or insulated from historical and political arguments as some of its detractors make out, the articulation of substantive political and moral positions has been far more explicit and prominent in recent work by theorists working within this tradition. Thus Harry Brighouse, Eamonn Callan, Graham Haydon, Meira Levinson, John White, Patricia White and Christopher Winch, to name but a few, have all developed accounts both of general educational aims and of subject-specific aims which, while written with the argumentative style and clarity so familiar to the analytic tradition, certainly do not aspire to offer a universal, 'neutral' or value-free account, and are explicitly situated within a particular political and historical context.

The second strand is philosophically oriented to the Aristotelian or neo-Aristotelian tradition, or to post-structuralism, and is characterized by a suspicion of the project of offering either a conceptual analysis of the structure of aims, or a defence of specific aims within a clearly articulated substantive moral or political position that is supposed to lead, logically and unproblematically, to prescriptions for educational policies, curricular design, and classroom practice.

As Standish puts this, 'the suspicion that emerges is that stating the aims of education may lead to a kind of stifling' (Standish, 1999, p. 42). Many philosophers of education working in this second vein have developed accounts of 'the goods internal to education' - accounts that go hand in hand with a concern that conceptualizing educational success in terms connected 
to the productive, political and economic sphere runs the risk of subverting or displacing these intrinsic goods (see Dunne, 2005; Hogan, 2009, 2010, 2011).

I will argue that both these approaches, due to their unexamined and unarticulated assumptions about the state, lead to a constriction of our ability to think about education, the political, the social and the relationship between these. A consideration of the anarchist perspective can, I suggest, open up our thinking and, in doing so, suggest a more critical and dynamic role for philosophy of education.

\section{Education Without Aims}

As explained above, although contemporary philosophers of education working within the analytic tradition have long ago abandoned the aspiration to provide a purely conceptual, second-order account of educational concepts and are generally explicit about their commitment to a set of substantive (liberal) values, their work often, as Standish suggests (1999, p. 40) takes the same 'discursive form' as older analytic accounts within this tradition, which offered, for example, defences of autonomy as an educational aim.

What concerns critics like Standish is that this type of philosophising about education seems to 'assume the possibility of an overview and the possibility of completeness' (Standish, 1995, p.133). In their critique of the idea of perfectibility and of the dominance of performativity in educational thought and practice (see Blake et al, 1998, 2000; Smith, 2002; Standish, 2007), these philosophers are not all invoking a defence of education as a practice; nor are they rejecting wholesale the traditional account of liberal education. Yet the suggestion that 'questions concerning the aims of education should then touch us with a faint sense of embarrassment' (Standish, 1995, p. 128) adds to the impression that any attempt to 
pin down and define education in a way that is 'too formulaic too explicit' (see Standish, 2012) risks losing something of its possibly ineffable qualities.

In this sense, Standish's work has affinities with that of philosophers like Dunne and Hogan who emphasise the intrinsic quality of educational practices and relationships. The political is often, in such accounts, implicitly regarded as something to be suspicious of. This is not to say that such accounts are devoid of political or historical analysis. Yet to the extent that politics appears at all in such work, it is either as something 'external' from which the practice of education must be protected in order to preserve its integrity, or as a 'system' which pre-exists any form of educational practice and can be defended or criticised independently of anthing we may wish to say about the practice of education.

Padraig Hogan defends this view particularly forcefully, arguing that educational practice needs to 'emerge from its historic subordination to paternalistic and bureaucratic masters, and to lay claim in an articulate and sure-footed way to its own identity as a human practice.' (Hogan, 2011, p. 30). His recent work consists of an articulation of the 'inherent purposes' of this practice and 'a recognisable family of virtues' that arise from it (ibid). While acknowledging that education is inescapably value-laden, Hogan wants to resist the idea that the values in question must be derived from 'particular individuals and groups'. 'Such a conclusion obscures the very possibility that education is a practice in its own right, with its own inherent purposes and ethical commitments. Instead, it defines education from the start as a subordinate practice.' (ibid)

From the perspective of this position, accounts like those of John White (1990, 2011), Reiss and White (2013), Levinson, (1999), Brighouse (2006, 2010) and Callan (1997) which explicitly defend a vew of the kind of education necessary in liberal state, both run the risk of 
'subverting' education and distorting its internal goods and suggest a dangerous form of closure (Standish, 1995).

As I will suggest below, both these perspectives share a similarly narrow view of the relationship between politics and education. What accounts for this narrowness, however, is not a view of educational aims and practices as 'subservient' to 'extrinsic' political ones, nor anything 'formal or procedural' (Standish, 2007, p. 163) in particular philosophical approaches, but rather the assumption of the state and the institutional framework of state education as the conceptual territory on which all debates about education take place, and a connectedly narrow view about the meaning of and possibilities for social change. These assumptions, I suggest, involve a serious lack of philosophical imagination.

\section{Politics and the State}

The (capitalist) state is there implicitly in the work of theorists within the analytic tradition from the 1970s, and explicitly in the work of prominent contemporary theorists such as Harry Brighouse, Richard Pring, John White, Partricia White, and Christopher Winch. Indeed one could argue that while this tradition was once centrally concerned with a defence of 'liberal education', it is now more accurately described as focused on 'education in the liberal state'. The conflation of liberal education with the liberal state is sometimes explicitly defended, as in Alan Ryan's contention that liberal education is 'the kind of education that sustains a liberal society' (Ryan, 1998, p. 27). Yet the state itself is rarely argued for by philosophers of education who, like most political philosophers, seem to assume that, however imperfect, it is somehow inevitable. 
It is certainly not true that in tacitly assuming the state as the normative framework for their discussion of education, theorists such as those mentioned above are ignoring wider, traditional 'liberal' aims to do with pursuing education for its own sake. Nor are such accounts devoid of critical political perspectives. Harry Brighouse $(2003,2010)$ and Christopher Winch (2000, 2005), for example, have defended accounts of liberal education that require far more interventionist policies of redistribution than those currently operating in most liberal state education systems. Winch's critical position, which combines a concern for those aspects of educational experience which cannot be reduced to instrumental or positional goods, with an engagement with the vocational aspects of education and the link between educational achievement and socio-economic outcomes, is most evident in his recent exchanges with James Tooley (see e.g. Sarangapani and Winch, 2010).

Winch has criticised Tooley for ignoring the social and political implications of private educational provision, as well as for his failure to appreciate the public good nature of education alongside its positional value. Yet while I have a great deal of sympathy for Winch's view, I want to suggest that positions like this, which assume the (capitalist) state as an inevitable feature of our lives - the worst consequences of which can, perhaps, be ameliorated through educational provision - narrow the horizon of our political imagination. Tooley's work is often described as 'radical' in that it imagines education without the state. Yet while Tooley $(1996,2000)$ has made an important contribution to philosophy of education in reminding us that 'education' is not equivalent to 'schooling' and in questioning the monopoly of state education, he begins, like his opponents, from the assumption that the state is the framework in which we are operating. In Tooley's market-driven alternative to schools controlled and funded by the state, the capitalist state is still very much there in the background - indeed, it constitutes the very structures and paradigms within which the 
market system can operate and within which the educational goods that it provides make sense.

Winch argues that re-constructing educational provision along the market-driven lines Tooley suggests will both encourage the kinds of attitudes and individual propensities that will undermine the humanistic elements of the form of liberal education that he wishes to defend, and entrench socio-economic gaps, leading to vast inequalities. While I would not disagree with this argument, I do want to reject the implication that there are only two options to choose from: either education provided and controlled by the liberal state, hopefully configured in such a way as to meet at least a minimum requirement of social justice, or educational provison within a private system operating on the logic of free-market capitalism.

Similarly, Harry Brighouse, in arguing against Tooley and other proponents of market or quasi-market reforms or parental choice policies in educational provision, assumes that the basic structure of the capitalist state will remain the same; all we can do is ameliorate its worst injustices. The main quarrel between him and Tooley is that, given this structure, Tooley does not think that the socio-economic disparities produced by differential educational opportunities will be any worse under a market-driven system than they are in a state-controlled system.

While Brighouse is careful to acknowledge that trying to equalize educational opportunity alone will not resolve the deficit of social justice, he, like most philosophers of education, takes the normative and practical framework of the state as a given and suggests that the role for political philosophers is to propose and critically analyse policies with the aim of bringing it closer to the Rawlsian model of a truly liberal, just state. By focusing on the fact that 'It is unfair, then, if some get a worse education than others because, through not fault of their 
own, this puts them at a disadvantage in the competition for these unequally distributed goods' (Brighouse, 2010, p, 27), Brighouse diverts attention from the idea that the capitalist state is characterised by competition for unequally distributed rewards, with educational attainment causally linked to such rewards,

Likewise, John White, whose recent work focuses on the notion of well-being as an aim of education, assumes the state framework. His very focus on the question of 'what schools are for', rather than what education is for, is indicative of this assumption. His account is also perhaps the most clear-cut example of the kind of 'neatness' that Standish worries about; its discursive form is indeed one in which the philosophical task is to 'begin with overarching aims, then fill them out in greater specificity' (Reiss and White, 2013, p. 1). While White is only too aware of the socio-economic context of human flourishing, and has emphasised throughout his work that 'basic needs have to be met' (ibid, p. 6) before one can even talk of well-being, his account does not start from a serious enquiry into what kind of social and political arrangements are most likely to secure these goods, but rather assumes the arrangements we have in place, albeit with a fairly critical view of their inadequacy. The state, here, is a given; our task is merely to delineate its 'proper role' (ibid, p. 48) and limits in determining the aims of schools. Thus in arguing that schools 'have a contribution to make in encouraging young people to [...] be sensible in managing money' (ibid, p. 6), White fails to acknowledge the ways in which this very argument assumes the capitalist state structure as a given. Similar assumptions can be found in the work of Brighouse who, in arguing that we should 'use schooling to enable children to interact with the economy in ways that facilitate their flourishing in their leisure time' (Brighouse, 2006, p. 41), assumes 'the economy' as a background constraint on what schools are and what they can and should do, rather than seeing it itself as part of a malleable socio-political structure than can and should be reconceptualized and challenged. Brighouse, like White, has focused on the idea of 
education for human flourishing in his recent work, yet he does not seem to regard it even worth explaining how such an idea can slide unproblematically into the claim that 'this means four central ideals that should inform the curriculum and ethos of schooling' (ibid, p. 131), without justifying the framework of the state and state schooling.

So even theorists who acknowledge, with Reiss and White (2013, p. 48), that the question of what education is for 'is essentially a political issue', assume the state as the unquestioned backdrop against which all contemporary philosophical debates about education take place. In doing so, they essentially reduce 'the political' to a discussion of policy.

It is worth pointing out that this is no less true of accounts like Hogan's which explicity reject the idea that education can have political aims. Thus when Hogan refers to 'the wide diversity of practices - from early childhood education to adult education to postgraduate research seminars - that education as a practice in its own right includes', (Hogan, 2011, p. 35) he is, in this very delineation, already assuming something like a state education system. I believe a similar assumption is operating in work by philosophers sympathetic to post-structuralist approaches. Thus one finds repeated references to 'the system' in the work of philosophers who have developed an eloquent critique of 'managerialist assumptions' (Blake at al, 1998; Hogan and Smith, 2003) and of what Richard Smith (Smith, 2002) describes as 'the instrumentalism, the techno-rationalism that runs through education at all levels'. Yet the absence of any reference to the state in such work suggests a failure to seriously consider the ways in which it may be, in fact, features of the state itself that are bound up with the problems these theorists identify in their critique.

Both accounts that implicitly assume the state in arguing for educational practice to be freed from politics, and accounts that explicitly defend the state out of a belief that it is the best 
guarantor of social justice show a serious lack of political and philosophical imagination. All of the theorists discussed above are, to be sure, critical, whether in their determination not to allow education to be harnessed to neo-liberal agendas and to worsen socio-economic disparities; or out of a concern not to allow schools, teachers and pupils to be dominated by the language of instrumental rationality. Yet in assuming the (capitalist) state as the backdrop against which this critical view of education takes place, rather than as the very thing that needs to be constantly acted against, they undermine the force of their own critique.

How many philosophers have dared to go further than the warning that 'Excessive positional advantage conferred by education may lead to outcomes that are harmful both to individuals and society through the production of excessive relative inequalities of income' (Sarangapani and Winch, 2010, p. 501) and to imagine a social world in which the very structures which give rise to 'positional advantage' have ceased to be relevant? How many have dared to imagine not just a world where poor or working class children's educational opportunities would not be restricted by their parental background, but in which there was no poverty and where society was not characterized by hierarchical divisions of class?

Brighouse states frankly that 'to achieve a fully just society [...] would require substantially more radical reform' (Brighouse, 2010, p. 65) than that which he is advocating, and admits that he sees 'no great prospects for such reform' (ibid). I want, in what follows, to explore what it would mean to take seriously, as anarchism does, the possibility of a truly equal and free society, organised non-heirarchically on the basis of cooperation, solidarity and mutual aid, and to consider how the anarchist position also encourages a very different view of what radical social change actually means. 
Yet in starting from such a radical idea, are we not already falling victim to the kind of trap that Standish warns us of? The temptation that if we can only work out what the perfect society would look like, we can then map out what kind of education we need to get us there, and work out how to 'deliver' it? An understanding of the anarchist view, as I will elaborate below, suggests that one can take seriously the point that education is bound up with political questions about the kind of social world we want, without falling into the trap described by Standish. The choice is not between defending the integrity of educational practice or allowing our educational thinking to become hostage to a kind of rational planning that runs the risk of subverting such practices by seeing them as subservient to political or economic ends. The anarchist position, I will argue, offers us an imaginative, critical and motivating vision of a good society, without proposing a programme of revolutionary social change that can be worked out in advance, or a total overthrow of the existing system. In so doing, it suggests a very different perspective on the relationship between education and social change.

\section{Education as Social Self-Liberation}

Many readers will no doubt balk at the idea of beginning our work as philosophers of education from such a 'utopian' vision. It is important, then, to pause for a moment to consider the different meanings and uses of the term 'utopian'. Saul Newman has described how, in the contemporary political landscape, dominated by implicit or explicit references to the 'inevitability' of capitalism, free-markets and neo-liberal assumptions, 'the word utopia has a precise ideological function: it operates as a way of stigmatising alternative political and economic visions as, at best, unrealistic and naive, and, at worst, dangerous.' (Newman, 
2009 , p. 209). There is, in fact, an interesting history of derogatory use of the term 'utopian' towards anarchism, although the precise content of the charge has varied depending on who was making it. I have discussed elsewhere (Suissa, 2006) how both the charge that anarchists have a naively optimistic account of human nature, thus rendering their position 'impractical', and the conflation (famously found in Popper and Berlin) of the term 'utopian' with the idea of a static state of perfection or a form of totalitarianism, can be rejected on the basis of a rigorous understanding of anarchist theory (see also Morland, 1997).

What I want to emphasis for the current discussion, though, are two points that are particularly pertinent to the educational questions under consideration. Firstly, the key point that the anarchist utopia does not consist of a blueprint for the future society; and secondly, the sense - so urgent and necessary in the current climate of 'no alternative' - in which utopian thinking, and the anarchist utopia in general - can fill the important positive function noted by so many theorists of utopia, namely that of 'generating constructive and dynamic critical thought' (Goodwin and Taylor, 1982, p. 27), and thereby 'relativising the present' (Bauman, 1976, p. 13). As Newman puts it, at a time when 'the very idea of utopia has been discredited', introducing a utopian dimension to political discussion and action can bring 'a kind of radical heterogeneity and disruptive opening into the economic, social, political and ideological constellation that goes by the name of global capitalism' (Newman, 2009, p. 208).

Taking on board these points, we can begin to see how anarchism suggests an understanding of the relationship between education and social change that sheds new light on the themes and tensions discussed above, and thus cannot be simply rejected as the kind of unrealistic 'more radical reform' that Brighouse refers to. For crucially, the kind of social transformation that anarchists envisage is one in which spheres of social action are gradually freed of 
relations of domination, a process which can go on within and alongside the existing structures of the state - as captured in the phrase 'building the new society in the shell of the old'. Thus anarchism, as Colin Ward explains, is 'not about strategies for revolution'; rather, 'far from being a speculative vision of a future society, it is a description of a mode of human organization, rooted in the experience of everyday life, which operates side by side with, and in spite of, the dominant authoritarian trends of our society.' (Ward, 1973, p.18).

The modes of human organization that Ward documented and engaged with ranged from housing, allotments, use of urban space and education. All these arenas constituted spaces in which individuals working collectively could enact anarchism as 'an act of social selfdetermination' (Ward, in Wilbert and White, 2011, p. 261). So rather than see education and schools - as either a process of preparing children for life in society as we know it, an inevitable reproduction of existing ideological structures, or a means to improving and strengthening liberal institutions through the nurturing of certain intellectual qualities or civic virtues, anarchism invites us to see educational activity as a site of social transformation. It is here that the key anarchist idea of prefigurative practice comes in, for it is central to the anarchist view that the means for creating the alternative, stateless society be commensurate with the ends; 'a transformative social movement must necessarily anticipate the ways and means of the hoped-for new society' (Tokar, in Gordon, 2009, p. 269).

On the anarchist view, as we do not and cannot know the form of the ideal society, it is essential to enable the free interplay of human imagination and experimentation as far as possible. This insistence, though, should not lead to the common misperception that anarchism means chaos or disorder. In fact, as Morris point out (2005, p. 8), '[anarchism] means the exact opposite of this. It means a society based on order. Anarchy means not chaos, or a lack of organisation, but a society based on the autonomy of the individual, on co- 
operation, one without rulers or coercive authority'. Likewise, it is misleading to see anarchism as focused simplistically on the abolition of the state. Yet while nuanced understandings of the operation of power, oppression, and the symbiotic relationship between state power and capitalism can arguably be found in early anarchist thinkers like Kropotkin (see Morris, 2004), it is nevertheless true that the many new social movements that constitute the contemporary anarchist scene place paticular emphasis on 'the generalization of the target of anarchist resistance from the state and capitalism to all forms of domination in society' (Gordon, 2009, p. 262). But, as Gordon argues, this resistance clearly does not lead to the positing of 'the idea of an end to "all" forms of domination' - indeed, such an idea would be nonsensical as 'we simply cannot think such a state of affairs since we do not possess the full list of features that should be absent from it' (ibid, pp. 264-265)

In light of such conceptual arguments, one can appreciate how, as Gordon puts it, 'diversity itself has ascended to the status of a core value in contemporary anarchism' (ibid, p. 266). Yet in many ways, this idea echoes the thought of earlier anarchist thinkers like Ward, especially concerning the demand for diversity in education. If we are truly to allow educational spaces to become spaces for prefigurative practice, it is essential that we give teachers, children, parents and educational theorists the freedom to engage creatively and experimentally with such spaces. As Ward says, 'experiment is the oxygen of education' (in Wilbert and White, p. 238).

On this view, educational activities become not just an important arena for prefigurative practice but, connectedly, a form of direct action. As Gordon notes, while direct action is often associated with actions undertaken in a 'preventative or destructive' approach, it also has a constructive sense central to the anarchist project whereby individuals, acting together, 
'directly pursue not only the prevention of injustices, but also the creation of alternative social relations free of hierarchy and domination' (Gordon, 2009, p. 269).

Anarchism's utopianism, then, consists of an imaginative critique of the present, without imposing a static vision of the utopian future or a blueprint for how to achieve it. Crucially, the anarchist perspective on social change suggests a radically different view of the relationship between education and social change from that of philosophers of education concerned to emphasise the way in which our educational thinking must go beyond existing arrangements. Thus Bridges, for example, argues that 'We cannot really conceive of education without reference to some selection of the human qualities we want to cultivate and of the kind of social world we expect or perhaps want our pupils to occupy' — and that this requires 'an inescapable responsibility to invoke some normative conception of the human qualities and the social world we see as desirable'. (Bridges, 2008, p. 466). But the anarchist view challenges this account both by positing a radically different view of 'the kind of social world we want our pupils to occupy' from that of the state, and by at the same time insisting that the way to achieve this is not by working out in advance which human qualities are necessary to bring about and sustain it and nurturing them through education, but by imagining and enacting this social world here and now in our social relationships - of which education is one.

What this suggests is, in fact, a reconceptualization of the social. The fixation on the state (see Miltrany, in Sylvan, 1993, p. 215) and its logic which, as I have argued above, characterises both those philosophical positions on education which reject the political as a contaminating factor and those which emphasise the political aspects of education, gives rise to a narrow view of the political. It is the state, in fact, which is associated with what Martin Buber referred to as 'the political principle', and which he distinguished from the social 
principle. Whereas the political principle 'is seen in power, authority and dominion', the social principle is seen in 'families, groups, unuion, cooperative bodies and communities' (Ward, in Wilbert and White, 2011, p. 268). While it seems naive to conceive of families and communities as devoid of issues of power and authority, nevertheless there is an important insight here, I think, in that it is the monopolizing of power by the state which weakens society conceived of as a network of spontaneous human self-organization. It is this same insight behind Gustav Landuaer's famous remark that 'the state is not something which can be destroyed by a revolution, but it is a condition, a certain relationship between human beings, a mode of human behaviour; we destroy it by contracting other relationships, by behaving differently' (in Ward, 1991, p. 85.).

The above discussion, in suggesting that we rethink the sense in which education is a social practice may seem to be not that different from accounts by philosophers of education like Dunne and Hogan. Yet education, understood in the way I have discussed, cannot be a practice with its own 'internal goods' any more than 'society' is a practice with its own internal goods. We cannot, then, talk of education 'without aims'; but nor can we articulate a set of aims derived from a fully worked-out model of 'the good society'. Any such model, without the built-in requirement of constant human experimentation, would be a dangerous abstraction that itself would undermine the possibilities for human freedom that it is intended to bring about. Yet concerns that thinking about the quality of educational practices in light of normative ethical ideas about the good society would somehow contaminate education, or that such normative ethical ideals go hand in hand with a dangerous form of closure are, in light of the above account, ill-conceived. A suspicion of closure and perfectibility should not lead us to abandoning the project of thinking about education as part of a normative, ethical project for transforming our life as individuals and as a society. For as Ward points out, 'The 
concept of a free society may be an abstraction, but that of a freer society is not.' (in White, 2011, p. 97).

Interestingly, Blake et al (1998), in developing the idea that educational institutions need 'to be released from the performativity...that has come to dominate them', (p. 189) make the point that there is no clear-cut prescriptive answer as to how to do this; the idea of a blueprint is, they say, 'at odds with' their very arguments, influenced as they are by poststructuralist thinkers, and they emphasise the need for more 'human scale' control (ibid). Their analysis could perhaps have been enriched by a serious consideration of anarchist thought, which, contrary to their claims about 'established traditions of progressive or radical theory' that they reject as not being 'dominant forces in the present educational scene' (ibid, p. 186), does not in fact hold an idealistic view of the social subject. For the anarchist position does not subscribe to an essentialist or metaphysical conception of human nature. Kropotkin, for example, was as scathing in his critique of Rousseau's notion of the benign, pre-social individual as he was in his rejection of the Hobbesian competitive, asocial individual. As Brian Morris points out, 'Marx, Bakunin and Kropotkin all critiqued - indeed ridiculed - these "abstract" conceptions of the human person long before Lacan and the poststructuralists' (Morris, 2009, p.15) ${ }^{\mathrm{i}}$

Joseph Dunne has discussed the way in which not just 'practical subjects but traditional academic subjects, can benefit from a conception of education more focused on the idea of a practice'. He defends the idea that it is, in the case of any subject, 'an ongoing practice that students need to be introduced to - a practice that embodies its own ways of conducting enquiry, asking fruitful questions, imagining or empathising with characters or situations, devising plausible hypotheses or interesting intepretations, sifting and weighing evidence, making creative connections or shifts of perspective [...].' (Dunne, 2005 p. 156). Similarly, 
Hogan $(2010,2011)$, articulates and defends 'the virtues of teaching and learning'. But while I would not want to reject these rich accounts of teaching and learning, I would add that the practice of education always takes place in a social space which is itself reflective of and embodies particular modes of organization and forms of interpersonal relationships; there is no escaping the question of how these relationships are constituted and what qualities they embody; those of domination, hierarchy and competitiveness, or those of commensality, mutual aid and spontaneity?

Theorists like Wilfred Carr are concerned with the way education has come to be seen 'less as a "practice" and more as a "system"" that had to be organised, managed and controlled so as to make it responsive to the political and economic demands of the modern industrial state'. (Carr, 2005, p. 41). Yet Carr's historical account not withstanding, it would be a mistake, in the process of trying to reclaim this sense of education as a practice, to jettison the sense of the practice of education as being inextricably bound up with social and political ideas and values, whether those of the industrial nation state or those of a very different conception of social life.

Going back to Buber's distinction between the political and the social, an anarchist philosophy of education not only transcends the dichotomy between 'intrinsic and extrinsic aims of education' (a dichotomy that has become something of an orthodoxy within the discipline), but can contribute to a theoretical and practical reclamation of and reaffirmation of the social. The state fixation which characterises so much work in political philosophy and philosophy of education has the effect not only, as I argued above, of seriously limiting our philosophical imagination, but also of squeezing out the social in the sense that Buber and Ward talk about it.

This point is developed by Bargu, as follows: 
From the perspective offered by traditons of mutuality, the crisis of modernity lies less in the invasion of the political by the social than in the flattening out of the social by the hegemonic construction of the autonomy of the political and the progressive destruction of the social by the incursion of a capitalist market whose primary form of competitive and individualist action has been detrimental to communal practices and relations. (Bargu, 2013, p.37).

For the social anarchist, the problem facing humans today is not, as Arendt would have it, 'the rise of the social and its invasion of the political', but rather the 'progressive constriction of the social by the juridicial conception of the political based on rights and liberties, on the one hand, and by the commercial relations of private exchange in the market on the other.' (ibid, p. 50)

Imagining a self-governing anarchist society free from relations of domination means, then, imagining a radical reconfiguration of the present, but also commiting ourselves to enacting this reconfiguration in countless diverse and possibly small ways, embodying the kind of prefigurative practice where 'subsistence and mutual aid, justice and fellowship are elements that we must seek in order to nourish, both literally and metaphorically, the new community'. (ibid).

\section{Objections}

It will be objected that, in the current political climate, to open up the possibility of siding with proponents of free educational experimentation outside the state system is a dangerous abandonment of the political terrain and a betrayal of the struggle for social justice, and will play into the hands of neo-liberal reformers. 
To this I would respond that to frame the debate as if one had to choose between a blanket defence of state education and an endorsement of neo-liberal, market-led forms of private educational provision is both to ignore the historical context of state education and to misrepresent the critical role of philosophy.

Educational philosophers on the political left are almost universally united against current proposals for 'free schools'. Yet as the history of working class initiatives in cooperative education, free schools, and experiments in cooperative living reminds us, the alternative to a state monopoly on education is not just free-market individualism or for-profit schools. Indeed, the tendency to polarise debates on issues like welfare and education can be seen as symptomatic of the ideological anti-utopian stance described above. We need to revisit and re-examine the history of these debates as part of an attempt to reclaim a more critical, emancipatory position. Carissa Honeywell (2011) has offered just such a contribution in her fascinating analysis of British social policy debates, drawing on the work of anarchist thinkers such as Ward, who describes how the political left in Britain 'invested all its fund of social inventiveness in the idea of the state, so that its own traditions of self-help and mutual aid were stifled for lack of ideological oxygen' (Ward, in Wilbert and White, p. 272). Revisiting these debates seems particularly urgent at a time when the traditional values of the socialist left are so under attack. As Ward remarked bitterly in 2000, 'The socialist ideal was rewritten as a world in which everyone was entitled to everything, but where nobody except the providers had any actual say about anything. We have been learning for years, in the antiwelfare backlash, what a very vulnerable utopia that was.' (ibid, p. 273). 
Philosophers, sociologists and historians of education can contribute to the project of reclaiming notions like 'community', 'freedom' and 'fairness' from the right and challenging contemporary ideological positions by articulating and documenting alternative educational ideas and experiments. Some philosophers of education have in fact been doing just that; yet even these theorists often overlook the anarchist position. Fielding and Moss, for example, in their book Radical Education and the Common School, (Fielding and Moss, 2011) explore and defend the pedagogical practice of radical educational experimenters such as Alex Bloom. Of course the book's title implies a tacit defence of the state (where, while the need for radical democratic education is rigorously defended, the need for state education is not). Yet even so, given that the notion of prefigurative practice features so centrally in their analysis, it is remarkable that the anarchist tradition, arguably the tradition most associated with this idea, and the most fruitful source of well-developed and rich accounts of its theoretical and practical implications, receives not even a passing mention.

Fielding and Moss, however, at least do an important job in reminding us that it is not state education as such that is a project worth defending, but only state education insofar as it instantiates human and social values such as justice, freedom and equality. This position is in fact implicit in accounts like those of Winch and Brighouse, who, in defending state education against attacks from right-wing libertarian and neo-liberal positions, are simply arguing that, given the political system we have, the unfair positional advantage conferred by education is more likely to be produced by the private sector.

As discussed above, framing the discussion as if there are only two options: universal compulsory state schooling which, while far from perfect, is the best guarantor of a minimal standard of universal educational provision and the best protection against parents' ability to exploit their unequal economic resources to confer educational advantage on their children - 
or a private market in educational provision, shuts down the possibility of imagining and allowing schools and other educational experiments where the utopian idea of a radically different society could be enacted freely through the kind of transfigurative practice described above. The point I want to make here is that we do not have to choose between either daring to imagine and to prefigure a society radically different from the kind we have now, or trying to ensure that, given the kind of society we live in, educational provision is not shaped by policies that adversely affect certain groups and privilege others. We can do both. Indeed, as Chomsky reminds us,

In today's world, I think, the goals of a committed anarchist should be to defend some state institutions from the attack against them, while trying at the same time to pry them open to more meaningful public participation - and ultimately, to dismantle them in a much more free society, if the appropriate circumstances can be achieved. (Chomsky, 1996, p. 75)

It is important to note, though, that in the same way as worries about the excesses of neoliberalism and capitalism should not lead political theorists concerned with social justice into blindly defending state education, nor should anarchists assume that all 'free schools' are necessarily better than those provided by the state. The anarchist commitment to prefigurative practice goes hand-in-hand with the insight of contemporary anarchists that 'resistance to all forms of domination in society moves its notions of social transformation beyond their previous formulation as the abolition of institutions to the redefinition of social patterns in all spheres of life, institutional or otherwise' (Gordon, 2009, p. 263), thus making sense of the fact that many anarchist educators work within the state system. But equally importantly, one has to pay careful attention to the political context in which possibilities for 'freeing' education from the state are being proposed. 
Buber's reference to 'the political surplus' of the state over society and the suggestion that we need to recover a richer notion of the social, is reminiscent of Nikolas Rose's account of how, in neo-liberal discourse, 'the unified space of the social is re-configured, and the abjected are relocated, in both imagination and strategy, in "marginalized spaces" [/...]" (Rose, 1996, p.347). I have argued that an anarchist perspective demands that we reclaim and enact a multiplicity and plurality of spaces for 'the social', redefining - and possibly reclaiming - in doing so, the very notion of the social and associated notions like community. How, where and to what extent this can be done in the current political climate is an open question. Certainly the current UK Coalition government's policy on free schools and academies is very far removed from any truly social, grass-roots initiatives, and seems rather more like what Rose has described as another form of politically centralized and hegemonic control by the state of spaces once thought of as 'social'. The individuals within such spaces and their very configuration are also, of course, subject to what Rose calls 'government by audit' (ibid, p. 351) - in this case educational forms of audit such as standardized testing and inspection regimes - which 'hold out the promise - however specious - of new distantiated forms of control between political centres of decision and the autonomized loci - schools, hospitals, firms, - who now have the responsibility for the government of health, wealth and happiness' (ibid).

Most 'free schools' in Britain today are indeed very different from the original free schools of the 60's and 70's, as Charkin (2011) reminds us. But nor should we be under the illusion that there was a golden age of 'free schools' in which such projects were immune to the kinds of entrenched privileges and social hierarchies which contemporary critics warn of. Kozol, a leading member of the 1970's free school movement, talked scathingly, as early as 1972, of people who go out 'into the mountains of Vermont' to start 'an isolated upper-class rural free school for the children of the white and rich' while still profiting from the consequences of 
the deeply unequal and racialized power relations that characterise US society (Kozol, 1972, pp. 5-12). Free schools he says, 'cannot with sanity, or with candor or with truth, endeavor to exist within a moral vacuum' (ibid, p.10). Yet this is not to say that there were not then, or now, and that one cannot imagine, genuinely free schools that engage with these issues of power, through a form of prefigurative practice, while at the same time perhaps exhibiting the 'virtues of teaching and learning' that philosophers such as Hogan have described. Indeed the history of radical educational experiments is full of examples of such schools (see Avrich, 2006; Gribble, 1998; Shotton, 1993; Smith, 1983). We should not, then, reject all freeschools outright simply because they do not fit in with a theoretical model of Rawlsian liberalism.

In defending Ward's particular brand of anarchism against Bookchin's claim about the 'unbridgeable chasm' between 'life-style anarchism' and 'social anarchism', Stuart White reminds us that a 'good deal of Ward's work is less concerned with mapping the possible future than with celebrating what people can and do experience here and now'. (White, 2011, p. 98). Perhaps philosophers of education, as part of the project to reclaim and articulate a truly critical position, should do a bit less mapping and a bit more celebrating. It may be difficult and sometimes frustrating trying to negotiate the tensions described by Chomsky, but acknowledging them will make our discipline both more lively and more politically engaged than pretending that we have resolved them. 'There is a certain kind of revolutionary courage', Kozol insists (1972, p. 72). 'in fighting for a new world and still helping men [sic] to live without ordeal in the one that they are stuck with'. I am not so arrogant (or deluded) as to presume that being a salaried academic philosopher requires this kind of courage; but surely it is part of our role as philosophers to explore and articulate different conceptual and practical possibilities from the ones dominating our political and academic discourse. By such philosophical work, alongside a commitment to genuine educational experimentation, 
we can multiply 'the political and also the social and imaginary ties people are subjected to,' (Bottici, 2013, p. 18) and thereby engage in a kind of utopianism of the present. For

...utopianism is above all about the present [...] The most utopian of utopianisms is also the most practical one. [...] It does not propose any 'metaphysics of presence' that posits an unmediated essential reality that somehow reveals to us its full being. Rather it is a radical empiricism of presence that allows what is present to present itself, to give itself as a miraculous gift. (Clark, 2009, p. 20)

My concern is that in our anxiety to shield education from the worst excesses of the language, logic and oppressive practices of managerialism, instrumental rationality, or free-market capitalism, we will forget that it is not just our education system, but our society that needs changing. And it is just possible that such change may come about not through a moment of revolutionary rupture, or through a scientifically worked-out programme of reform, but by allowing educational spaces to become sites for prefigurative practice. The task for philosophers of education, then, is to imagine what such spaces might look like; to articulate the values and ideas that they embody; to celebrate and engage with them, and to defend their possibility, while ever vigilant of their dangers.

\section{$\underline{\text { References }}$}

Avrich, P. (2006) The Modern School Movement; Anarchism and Education in the United States, Oakland: AK Press.

Bargu, B. (2013) 'The politics of commensality', in J. Blumenfield, Ciiara Bottici and Simon Critchley (eds), The Anarchist Turn, London: Pluto Press. 
Bauman, Z. (1976) Socialism: The Active Utopia, New York: Holmes and Meier.

Blake, Smeyers, P., Smith, R. and Standish, P. (eds) (2000) Education in an Age of Nihilism, Abingdon: Routledge.

Blake, N., Smeyers, P., Smith, R. and Standish, P. (eds) (1998) Thinking Again: Education After Postmodernism, Westport: Bergin \& Garvey.

Bottici, C. (2013) 'Black and red: The freedom of equals', in J. Lumenfield et al.

Bridges, D. (2008) 'Educationalization: On the appropriateness of asking educational institutions to solve social and economic problems', Educational Theory, 58 (4) 461-474.

Brighouse, H. (2010) 'Educational equality and school reform', in G. Haydon (ed.)

Educational Equality, London: Continuum, pp. 15-69.

Brighouse, H. (2006) On Education, Abingdon: Routledge.

Brighouse (2003) School Choice and Social Justice, Oxford: Oxfrod University Press.

Callan, E. (1997) Creating Citizens: Political Education and Liberal Democracy, Oxford: Clarendon Press.

Carr, W. (2005) 'Philosophy and Education' in W. Carr (ed.) The RoutledgeFalmer Reader in Philosophy of Education, Abingdon: Routledge, pp. 145-160.

Charkin, E. (2011) 'For a real free school look to postwar Pekham', The Guardian, Comment is Free, 30 August. http://www.guardian.co.uk/commentisfree/2011/aug/30/free-schoolpeckham-education 
Chomsky, N. (1996) Powers and Prospects: Reflections on Human Nature and the Social Order, Boston MA: South End Press.

Clark, J.P. (2009) 'Anarchy and the dialectic of utopia', in L. Davis and R. Kinna (eds), Anarchism and Utopianism, Manchester: Manchester University Press, pp. 9-29.

Davis, L. (2009) 'Introduction', in L. Davis and R. Kinna, pp. 1-5.

Dunne, J. (2005) 'What's the good of education?' in W. Carr (ed.) The RoutledgeFalmer Reader in Philosophy of Education, Abingdon: Routledge, pp. 145-160.

Fielding, M. and Moss, P. (2011) Radical Education and The Common School; A Democratic Alternative, Abingdon: Routledge.

Goodwin, B. and Taylor, K. (1982) The Politics of Utopia: A Study in Theory and Practice, London: Hutchinson.

Gordon, U. (2009) 'Utopia in contemporary anarchism', in L. Davis and R. Kinna, pp.260275.

Gribble, D. (1998) Real Education; Varieties of Freedom, Bristol: Libertarian Education Hogan, P. (2011) 'The ethical orientations of education as a practice in its own right', Ethics and Education, 6 (1), 27-40

Hogan, P. (2010) 'Preface to an ethics of education as a practice in its own right', Ethics and Education, 5 (2), 85-98

Hogan, P. (2009) The New Significance of Learning: Imagination's Heartwork, London: Routledge. Hogan, P. And Smith, R. (2003) 'The activity of philosophy and the practice of education', in N.Blake, P.Smeyers, R. Smith and P. Standish (eds), The Blackwell Guide to the Philosophy of Education, Oxford: Blackwell, pp. 165-180. 
Honeywell, C. (2011) A British Anarchist Tradition: Herbert Read, Alex Comfort and Colin

Ward, New York: Continuum.

Johnson, R. (1987) "“Really Useful Knowledge": Radical Education and Working Class Culture, 1790-1848', in J. Clarke, C. Critcher and Richard Johnson (eds), Working Class Culture: Studies in History and Theory, London: Century Hutchinson Ltd., pp. 75-102. Kozol, J. (1972) Free Schools, Boston: Houghton Mifflin Company.

Levinson, M. (1999) The Demands of Liberal Education, Oxford: Oxford University Press. Morland, D. (1997) Demanding the Impossible? Human Nature and Politics in Nineteenth Century Social Anarchism, London: Cassell.

Morris, B. (2009) 'Kropotkin and the post-structuralist critique of anarchism', Social Anarchism, 44, $5-21$.

Morris, B. (2005) Anthropology and Anarchy: their elective affinity, London: Goldsmiths Anthropology Research Papers.

Morris, Brian (2004) Kropotkin: The Politics of Community Amherst: Humanity Books. Reiss, M. and White, J. (2013) An Aims-Based Curriculum; The Significance of Human Flourishing for Schools, London: Institute of Education Press.

Rose, J. (2010) The Intellectual Life of the British Working Classes, New Haven: Yale. Rose, N. (1996) 'The death of the social? Refiguring the territory of government', Economy and Society, $25(3), 327-356$.

Ryan, A. (1998) Liberal Anxieties and Liberal Education, New York: Hill and Wang Sarangapani, P. M. and Winch, C. (2010) 'Tooley, Dixon and Gomathi on private education in Hyderabad: a reply', Oxford Review of Education, 36 (4), 499 -515.

Shotton, J. (1993) No Master High or Low; Libertarian Education and Schooling in Britain, 1890-1990, Bristol: Libertarian Education.

Smith, M. (1983) The Libertarians and Education, London: George Allen and Unwin Smith, R. (2002) 'Sustainable learning', The Trumpeter, 18 (1). 
Standish, P. (2007) 'Rival conceptions of the philosophy of education', Ethics and Education, $2(2), 159-171$.

Standish, P. (1999) 'Education without aims?' in R. Marples, (ed.) The Aims of Education, London: Routledge, pp. 35-49.

Standish, P. (1995) 'Postmodernism and the education of the whole person', Journal of Philosophy of Education, 29 (1), 121-135

Suissa, J. (2006) Anarchism and Education, London: Routledge.

Sylvan, R. (1993) 'Anarchism,' in R.E. Goodin and P. Pettit (eds) $\underline{\text { A Companion to }}$

Contemporary Political Philosophy, Oxford: Blackwell.

Tooley, J. (2000) Reclaiming Education, London: Cassell.

Tooley, J. (1996) Education Without the State, London: Institute of Economic Affairs.

Ward, C. (1991) Influences; Voices of Creative Dissent, Bideford: Green Books.

Ward, C. (1973) Anarchy in Action London: Allen \& Unwin.

White, J. (1990) Education and the Good Life: Beyond the National Curriculum, London:

Kogan Page.

White, J. (2011) Exploring Well-Being in Schools, Abgindon: Oxford.

White, J. (2010) 'Elusive rivalry? Conceptions of the philosophy of education', Ethics and

Education, 5 (2), 135-145

White, S. (2011) 'Social anarchism, lifestyle anarchism, and the anarchism of Colin Ward,' Anarchist Studies, 19 (2) 92-104.

Wilbert, C. and White, D. (eds) (2011) Autonomy, Solidarity, Possibility; The Colin Ward

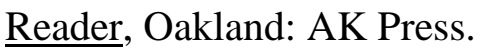

Winch, C. (2005) Education, Autonomy and Critical Thinking, London: Routledge.

Winch, C. (2000) Education, Work and Social Capital: Towards a New Conception of Vocational Education, London: Routledge. 
' In fact the anarchist position described here may have affinities with the kind of Emersonian perfectionism which Standish, drawing on Cavell, discusses in his work, and contrasts with 'ideas of the realisable perfectibility of human kind' (Blake et al, 2000, p. 153). 